cycles, increasing for a few years then returning to normal levels. In Napa, we've been waiting for 6 years for Pierce's disease to return to normal levels, but it seems to just keep getting worse."

Why is the incidence of Pierce's disease on the rise? Weber speculates there are five possible reasons: more vineyards, planted to meet rising demand for quality wines; more habitat for sharpshooters, such as ornamental landscapes; inadvertent spread of infected insects by workers or managers; reduced insecticide use, and more young vines, which are more susceptible to the disease. Napa growers have recently replanted many vineyards on rootstock resistant to phylloxera, a vine-destroying insect that also posed grave threats to North Coast vineyards.

Napa's recent warm winters may be contributing to the epidemic. The disease does not occur in areas with cold winter climates.

Current control methods include pesticide spraying of riparian vegetation bordering vineyards, and the vineyards themselves. Dimethoate insecticide can only be applied with a special permit. Imidacloprid is registered for use on grapes but is not specifically approved for use against Pierce's disease vectors. $-E d$.

\title{
Research
}

\section{Oak woodlands harbor greatest biodiversity}

$\mathrm{UC}$ and other research in the last decade has shown that oak woodlands, which cover almost $10 \%$ of California's 100 million acres, harbor the richest biological diversity of any major habitat in the state. They are home to some 2,000 species of plants, 170 birds, 100 mammals, 60 amphibians and reptiles and 4,000 species of insects. In addition to their values for wildlife, oak trees and associated vegetation improve water quality, control soil erosion, and provide outdoor recreation and aesthetic values.

In this issue, UC researchers report on biological diversity in oak woodland at Camp Roberts, a military facility overlapping San Luis Obispo and Monterey counties (see p. 8). The base encompasses certain oak woodlands that are unusual for their numerous oak snags, a flourishing understory of oak saplings and shrubs, and ground cover that includes many native forbs and downed woody material - an intact habitat structure that provides homes for many vertebrate species. In many oak woodlands, these habitat components have been altered or removed by intensive burning, development, agriculture, wood cutting or road building. The scientists will use their data as a baseline for evaluating the effects of such disturbances on animals in oak woodland.

In October, the researchers, in cooperation with the California Department of Forestry and Fire Protection and Camp Roberts Fire Department, conducted prescribed burning treatments on some of their study plots and are now assessing the responses of the animals they have monitored.

Landowners, developers and local planners also play important roles in the management of the state's oak woodlands. More than $80 \%$ of California oak woodlands are in private ownership, and most land-use planning is done at the local level. UC's Integrated Hardwood Range Management Program (IHRMP) is working with UC Extension advisors and faculty and state agencies to help landowners and land-use planners maintain old and new enterprises in oak woodlands, while sustaining wildlife and other natural resources.

Recent, unprecedented demand for California wine grapes has led to increasing development of vineyards on oak woodland upslopes, historically considered marginal for intensive agriculture. Removal of native trees, conversion of riparian areas, and establishment of large monocultures all pose threats to biological diversity. To promote sustainable development and management of California vineyards, IHRMP has developed a new extension curriculum for grape growers: "Vineyards in an Oak Landscape." The curriculum is coordinated by IHRMP director Richard Standiford, graduate student Julia Crawford, and extension specialist Adina Merenlender.

For more information, call Adina Merenlender, (707) 744-1424. $-E d$.

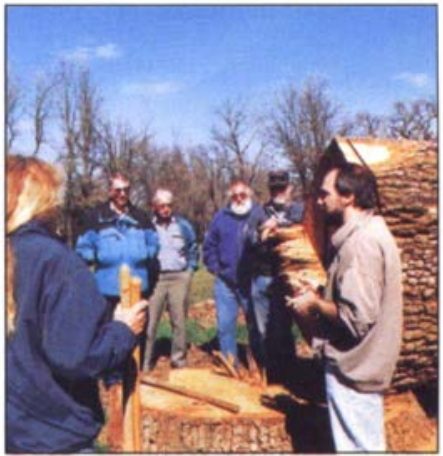

Dave Rizzo, UC Davis plant pathologist, gives a training session on protecting oak woodlands. 